Acta vet. scand. $1973,14,700-711$.

From the Norwegian Food Research Institute, Ås, Norway and the Department of Microbiology and Immunology, Veterinary College of Norway, Oslo.

\title{
PROTEASES OF CLOSTRIDIUM BOTULINUM
}

\author{
V. STUDIES ON THE SEROLOGICAL RELATIONSHIP \\ BETWEEN PROTEASES FROM \\ CLOSTRIDIUM BOTULINUM AND OTHER SPORE-FORMING \\ BACTERIA
}

By

Tore Bjarne Tjaberg and Kåre Fossum

\begin{abstract}
TJABERG, TORE BJARNE and KÅRE FOSSUM: Proteases of Clostridium botulinum. V. Studies on the serological relationship between proteases from Clostridium botulinum and other spore-forming bacteria. Acta vet. scand. 1973, 1/, 700-711. - By the use of the electrophoretic casein precipitating inhibition test (CPI-test) the serological relationship between proteolytic enzymes produced by different species within the genera Clostridium and Bacillus has been tested. The proteases produced by Clostridium botulinum types A, B, C, D and F cross-reacted with each other. Clostridium botulinum strain 84 was inhibited by antiproteases produced against Clostridium sporogenes, Clostridium botulinum types $\mathrm{C}$ and $\mathrm{F}$ (protease $\mathrm{F}$ I and F II), but not by antiproteases against Clostridium botulinum types $B$ and $F$ (protease II), Clostridium bifermentans and Clostridium perfringens. The protease of the newly described Clostridium botulinum strain 89 (type G) was inhibited by Clostridium sporogenes antiprotease, but not by any of the other antiproteases. It is not possible to differentiate between Clostridium botulinum, Clostridium sporogenes and Clostridium perfringens by use of serological differentiation of their proteolytic enzymes. The protease of Clostridium bifermentans is not serologically related to any of the species tested in this investigation. Proteases produced by different Bacilli were not inhibited by antiproteases from Clostridium botulinum types $\mathrm{B}, \mathrm{C}$ and F, Clostridium sporogenes, Clostridium bifermentans, and the two strains of Clostridium perfringens tested. This investigation indicates a serological relationship between proteases from different Clostridium species, but not a serological relationship between proteases produced by the Clostridium species and Bacillus species tested.
\end{abstract}

Clostridium botulinum; proteases.

Classification of the genus Clostridium is difficult and is currently based on morphological, biochemical and serological tests. Spore shape and location have been used as important characteristics to differentiate between species of clostridia. For 
the toxic or pathogenic species, in vivo neutralization or protection tests using specific antitoxin are the most reliable diagnostic methods.

The serological characteristics of Clostridium botulinum appear complex as is to be expected of motile organisms that contain $\mathrm{H}$ and $\mathrm{O}$ antigens and are also heterogeneous culturally. A serological grouping of the proteolytic clostridia was proposed by Mandia (1955). The primary classification was based on heatstable and heat-labile antigens. The proteolytic Clostridium botulinum types $A$ and $B$ examined belonged to group $B$ on the basis of possessing the unique heat-stable antigen and the heatlabile antigen. These strains of Clostridium botulinum shared one heat-stable antigen with Clostridium sporogenes, Clostridium histolyticum and Clostridium tetani.

Using fluorescent antibody technique and antisera prepared with heated suspensions of cells of types A and B Walker \& Batty (1964) found cross-reactions between proteolytic strains of $A, B$ and $F$, and between strains of $C$ and $D$, while type $E$ strains appeared homogeneous and distinct.

The immunological relationship between various strains of Clostridium botulinum and other anaerobic, spore-forming bacteria, using their somatic antigens, has also been investigated by the Division of Microbiology, Bureau of Science, FDA (1969). Their methods included tube agglutination, agglutinin absorption and indirect fluorescent antibody techniques. The results of this investigation indicated a system which classified Clostridium botulinum according to the proteolytic activity rather than by the specific toxins produced by each type. Clostridium botulinum type $E$ and its non-toxigenic variants shared common somatic antigens with non-proteolytic strains of types B and F. Another serological group incorporated Clostridium botulinum type A and the proteolytic strains of types B and F. Clostridium sporogenes also agglutinated with antisera of this group, but to a lower titre.

Lee \& Riemann (1970) examined the genetic relationship of various toxic and non-toxic Clostridium botulinum strains and found that the various strains could be grouped according to DNA-binding homology rather than DNA composition. Clostridium botulinum type $\mathrm{E}$ (strain Minn) was $100 \%$ homologous to the non-proteolytic B- and F-types used in investigation. Clostridium botulinum types $\mathrm{A}, \mathrm{B}$ and $\mathrm{OS}$ (non-toxic) variants of $\mathrm{E}$ had 
only 6 to $14 \%$ homology with Clostridium botulinum type $\mathrm{E}$ (strain Minn).

Polyacrylamide gel electrophoresis of vegetative cell extracts of different types of Clostridium botulinum (Hobbs \& Anderson 1967) revealed that the different types tested gave different and characteristic protein patterns. On the basis of this technique it should be possible to distinguish between the different types of Clostridium botulinum. Smith \& Holdeman (1968) divided the species Clostridium botulinum into three groups: 1) the proteolytic strains consisting of type $A$ and proteolytic $B$ and $F, 2$ ) the non-proteolytic strains of $B$ and $F$ and strains of type $E$, and 3 ) the strains of types $C$ and $D$.

Sandvik (1962) described an immunoelectrophoretic method for the serological differentiation of extracellular bacterial proteases. Specific antiproteases in immune rabbit serums were separated from normal protease inhibitors by paper electrophoresis, after which their antiproteolytic effect was demonstrated by inhibiting the specific enzyme from precipitating sodium caseinate in an agar medium. It was shown that many serologically different proteolytic enzymes were produced by a number of aerobic and facultatively anaerobic bacteria. Most of the enzymes were specific for species, and cross-reactions between species and genera were exceptional.

Hausken (1967) used this method in order to investigate the serological relationship between proteases produced by various Clostridium species. He found a close relationship between the proteases produced by Clostridium perfringens, Clostridium sporogenes and Clostridium parasporogenes. Proteases produced by some types of Clostridium botulinum were found to be inhibited by antiproteases produced by Clostridium perfringens. However, antisera were not produced against Clostridium botulinum proteases.

The aim of the present work was to obtain more detailed information about the serological relationship of proteases produced by some Clostridium species.

\section{MATERIALS AND METHODS}

\section{Organisms}

Proteases from the following strains were used for the production of antiproteases: 
Clostridium botulinum type B (strain Beans), Clostridium botulinum type C (strain Cid proteolytic), Clostridium botulinum type $F$ (strain Langeland), Clostridium sporogenes (ATCC* 7955), Clostridium bifermentans (ATCC 19299), Clostridium perfringens (ATCC. $3626)$, Clostridium perfringens $\left(\mathrm{NVH}^{* *} 843\right)$ and purified protease II from Clostridium botulinum type $F$ (strain Langeland).

Proteases from the following strains were used in the present investigation:

Clostridium botulinum type A (strain 62), Clostridium botulinum type B (strain Beans), Clostridium botulinum type C (strain Cid proteolytic), Clostridium botulinum type D (strain DIR), Clostridium botulinum type F (strain Langeland), Clostridium botulinum (strain 89), Clostridium botulinum (strain 84 SC 2), Clostridium sporogenes (ATCC 7955), Clostridium bifermentans (ATCC 19299), Clostridium perfringens (NCTC** 8237), Clostridium perfringens (ATCC 3626), Clostridium perfringens (NVH 839), Clostridium perfringens (NVH 843), Bacillus megaterium (ATCC 14581), Bacillus cereus (ATCC 14579), Bacillus licheniformis (ATCC 14580) and Bacillus subtilis (ATCC 6051). Strains 84 (SC 2) and 89 of Clostridium botulinum were kindly provided by Professor F. Giménez, Facultad de Ciencias Médicas, Mendoza, Argentina.

\section{Enzymes}

Proteases from Clostridium botulinum types A, B, C, D and F were produced on skim milk medium (Tjaberg 1973 a) and further concentrated as described by (Tjaberg $1973 \mathrm{~b}$ ). The other Clostridia were cultivated on Robertson's meat broth (Robertson 1915-1916) and incubated at $37^{\circ} \mathrm{C}$ for 2 to 4 days for protease production. The Bacillus species were cultivated on peptone water (Sandvik 1960) and incubated at $37^{\circ} \mathrm{C}$ for 4 days for protease production. The partially purified proteases of Clostridium botulinum types A, B, C, D and F were diluted and used in the electrophoretic CPI-test. Liquid cultures were centrifuged and the enzymes in the supernatants were used directly or diluted without further purification. The proteolytic activity was tested in the medium developed by Sandvik (1962).

\section{Production of antisera}

Antisera were produced in rabbits by s.c. or i.c. injection of

* American Type Culture Collection, Rockville, Maryland, USA.

* The Culture Collection at the Department of Microbiology and Immunology, Veterinary College of Norway.

* * National Collection of Type Cultures, London, England. 
the proteases mixed with equal amounts of Freund's complete or incomplete adjuvant (Difco) as described by Sandvik (1962).

\section{Electrophoretic differentiation of the serum inhibitors}

The sera were subjected to paper electrophoresis to separate the normal inhibitors in serum from the specific inhibitors produced (Sandvik 1962). An electrophoresis apparatus 3276 BN, LKB, Stockholm was used with Schleicher and Schüll filter paper, No. $2043 \mathrm{bmgl}(40 \times 410 \mathrm{~mm})$. Phosphate buffer, $0.05 \mathrm{M}$, pH 6.2 with thimerosal added to a final concentration of $1: 10,000$ was used. The sera were applied in amounts of $8-12 \mu l$ and subjected to electrophoresis at $120 \mathrm{v}$ for $16-18 \mathrm{hrs}$. The paper strips were transferred immediately to the surface of the caseinate-containing agar.

After incubation at $37^{\circ} \mathrm{C}$ for $2-3 \mathrm{hrs}$, the strips were removed and replaced by narrow $(4 \mathrm{~mm})$ strips of filter paper which were moistened with solutions of the enzymes to be tested. Usually three filter paper strips were placed in parallel, within the $4 \mathrm{~cm}$ broad field of the electrophoresis paper, and incubated for $5-24 \mathrm{hrs}$. at $37^{\circ} \mathrm{C}$.

Precipitation zones occurred along the enzyme-containing strips. Inhibition is indicated by interruption of the white precipitation zones, or by a narrowing of the precipitation zones depending upon the inhibitory activity and the enzyme concentration. The normal inhibitors in serum are localized on the anode side of the line of application. The combination of electrophoresis of inhibitor-containing material and the use of the casein precipitating inhibition test is referred to as the electrophoretic CPI-test (Fossum 1970).

\section{RESULTS}

Table 1 and Figure 1 show the results of the serological testing of proteases produced by various types and strains of Clostridium botulinum when tested against antiproteases produced against various clostridial proteases. The proteases produced by various types of Clostridium botulinum ( $A, B, C, D$ and $F$ ) were inhibited by antisera produced against Clostridium botulinum proteases type $\mathrm{B}, \mathrm{C}$ and $\mathrm{F}$, as well as against Clostridium sporogenes, and the two strains of Clostridium perfringens. Antibodies against partly purified protease II from Clostridium botulinum 
Table 1. Proteases produced by various types and strains of Clostridium botulinum tested against various clostridial antiproteases.

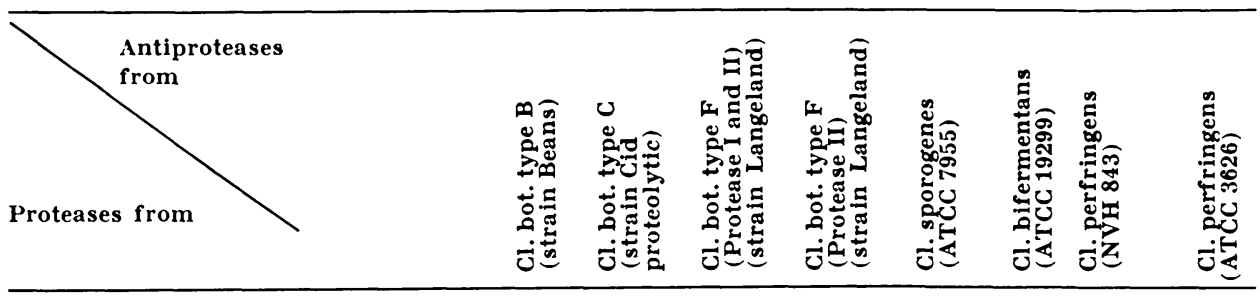

Cl. botulinum type $\mathrm{A}$ (strain 62) (Proíease I)

Cl. botulinum type A (strain 62) (Protease II)

Cl. botulinum type B (strain Beans) (Protease I)

Cl. botulinum type B (strain Beans) (Protease II)

Cl. botulinum type C (strain Cid proteolytic)

Cl. botulinum type D (strain DIR)

Cl. botulinum type $\mathrm{F}$

$$
\begin{aligned}
& ++^{*}++++++++-++ \\
& +++++++++-++ \\
& ++++++++t+t \\
& ++++++++t+ \\
& ++++++++++t \\
& +++++++++-+++
\end{aligned}
$$$$
\text { (strain Langeland) }
$$$$
\text { (Protease I) }
$$

Cl. botulinum type F

(strain Langeland)

(Protease II)

Cl. botulinum type 84

Cl. botulinum type 89

* ++ : inhibitory effect equal to homologous reaction.

$+\quad$ : inhibitory effect, but less than obtained by homologous reaction.

- : no inhibitory effect.

type $F$ had the same effect as had antibodies against the crude enzyme solution of type $F$, except that it did not cross-react with Clostridium botulinum strain 84 . The two proteases by Clostridium botulinum types $A, B$ and $F$, respectively, reacted in the same way for all antisera tested. Protease from Clostridium botulinum strain 84 gave a reaction with Clostridium botulinum types $\mathrm{C}$ and $\mathrm{F}$ antisera, as well as with antisera against Clostridium sporogenes protease, while Clostridium botulinum (strain 89) showed cross-reacting only with Clostridium sporogenes. No enzymoserological cross-reactions were observed between the latter two strains and Clostridium perfringens. No cross-reactions 


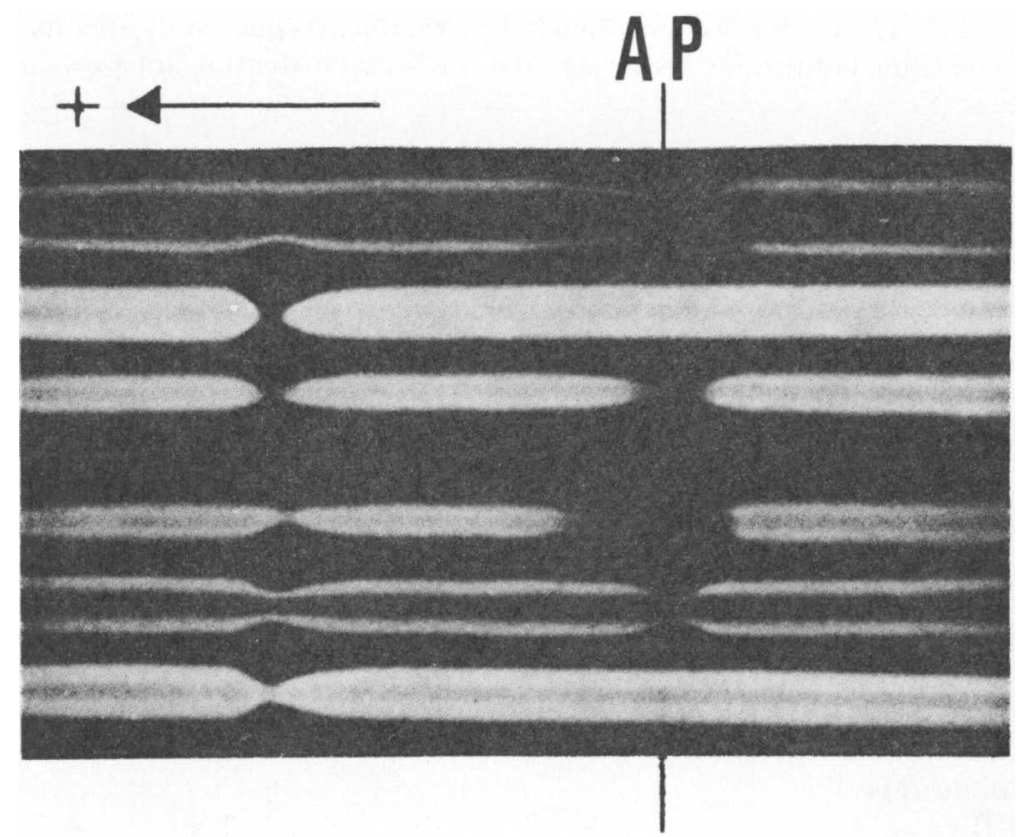

F i g u r e 1. Electrophoretic CPI-test of serum from rabbit immunized with proteases produced by Clostridium botulinum type $F$ (strain Langeland). The enzymes used are (downwards): Proteases from Clostridium botulinum type B (strain Beans), Clostridium bifermentans, Clostridium perfringens (NCTC 8237), Clostridium botulinum type F (strain Langeland), Clostridium perfringens (NVH 839) and Bacillus cereus (ATCC 14579). The electrophoresis was carried out in $0.05 \mathrm{M}$ phosphate buffer at $\mathrm{pH} 6.2$ for $18 \mathrm{hrs}$. The zone of inhibition near the line of application (AP) is due to the induced antienzyme against Clostridium botulinum type $F$ protease, while the zones on the anode side are due to the naturally occurring inhibitors in rabbit serum.

were observed between any types of Clostridium botulinum protease and Clostridium bifermentans protease.

Table 2 shows the results of the serological tests of proteases produced by various Clostridium and Bacillus species when tested against the same antiproteases as shown in Table 1. It can be seen that serological relationship exists between the proteases produced by Clostridium sporogenes, and various strains of Clostridium perfringens. The protease produced by Clostridium bifermentans does not react with any of the antisera tested except the homologous. None of the Bacillus proteases tested was inhibited by any of the clostridial antisera. 
T a b l e 2. Proteases produced by various Clostridia and Bacilli tested against various clostridial antiproteases.

\begin{tabular}{llllllll}
\hline & & & \\
Antiproteases \\
from
\end{tabular}

Cl. sporogenes

(ATCC 7955)

Cl. bifermentans

(ATCC 19299)

Cl. perfringens

(NCTC)

Cl. perfringens

(NVH 839)

Cl. perfringens

(ATCC 3626)

Cl. perfringens

(NVH 843)

Bacillus megaterium

(ATCC 14581)

Bacillus cereus

(ATCC 14579)

Bacillus licheniformis

(ATCC 14580)

Bacillus subtilis

(ATCC 6051)

$$
+++++++++-++++
$$$$
\text { - - - - }-+-
$$$$
+++++++++-++++
$$$$
+++++++++-++++
$$$$
+++++++++-++++
$$$$
+++++++++-+++
$$$$
\text { - - - - - - - }
$$

\section{DISCUSSION}

The present investigation shows that there are serological relationships between the proteases produced by different species of clostridia. The proteolytic strains of Clostridium botulinum used in this investigation cross-reacted to a large extent. The proteolytic Clostridium botulinum type $A$ and the proteolytic strains of types $B$ and $F$ are often considered to be one metabolic group, while the non-proteolytic types $C$ and $D$ are considered as another specialized group (Smith \& Holdeman 1968). The present study shows that there is a close relationship between these two groups, as the weakly toxic and proteolytic Clostridium botulinum types $C$ and D cross-reacted enzymoserologically with Clostridium botulinum types $B$ and $F$. The two proteases from types $A, B$ and $F$ reacted in the same way against the various antisera, 
and this could indicate a very close relationship. Clostridium botulinum strain 89 is considered to be the prototype of Clostridium botulinum type G (Giménez \& Ciccarelli 1970 a). Proteases from Clostridium botulinum strain 89 gave negative reactions against antiproteases for types B, C and F and weakly positive reactions with antiproteases against Clostridium sporogenes. Although the toxin produced by this species seems to give the characteristic symptoms of botulinum intoxication it may be worthwhile to investigate this matter further, since the protease produced by this species does not react in the same way as the other Clostridium botulinum types do. The strains are only weakly proteolytic, so it has not been possible to produce antibodies against these proteases so far. Clostridium botulinum (strain 84) is closely related to Clostridium botulinum type $A$, but the toxin behaves as a single complex of two different toxic molecules that possess antigenic determinants for both type $\mathrm{A}$ and type $\mathrm{F}$ toxins (Giménez \& Ciccarelli $1970 \mathrm{~b}$ ). The protease produced by this strain cross-reacted with Clostridium botulinum types $\mathrm{C}$ and $\mathrm{F}$ and Clostridium sporogenes proteases. The relationship between this strain and Clostridium botulinum seems to be better established than for strain 89, although further investigation is necessary. Antibodies against one of the two proteases of Clostridium botulinum type F (F II) inhibited the same enzymes as did antibodies produced with crude protease from Clostridium botulinum type $F$, except that it did not inhibit protease produced by the 84 strain. It inhibited protease I produced by Clostridium botulinum type $F$, which indicates a close serological relationship between the two proteases produced by Clostridium botulinum type F. Based on their extracellular proteases, it is not possible to differentiate between Clostridium botulinum, Clostridium sporogenes and Clostridium perfringens by the use of the electrophoretic CPI-test. Proteolytic strains of Clostridium botulinum may be confused morphologically with Clostridium sporogenes, and it is known that Clostridium botulinum shares one heat-stable antigen with Clostridium sporogenes (Mandia 1955). Using the fluorescent antibody technique some investigators have found crossreactions with Clostridium sporogenes (Bulatova \& Kabanova 1960 ), while others (Walker \& Batty 1964) have found no crossreaction between Clostridium botulinum and Clostridium sporogenes using a similar method. Division of Microbiology, Bureau of Science, FDA (1969) also reported a cross-reaction between 
Clostridium sporogenes and proteolytic Clostridium botulinum types A, B and F. Hausken (1967) showed that antiproteases from two types of Clostridium perfringens cross-reacted with Clostridium botulinum types A, B and E proteases. In the present investigation it was found that proteases from four strains of Clostridium perfringens cross-reacted with Clostridium botulinum types B, C and F. Proteases from Clostridium bifermentans do not cross-react with any other than the homologous protease, and none of the proteases produced by the various clostridia and bacilli cross-reacted with proteases from Clostridium bifermentans. It should be possible therefore, to use the electrophoretic CPI-test for the taxonomic identification of Clostridium bifermentans.

Proteases from Bacillus megaterium, Bacillus cereus, Bacillus licheniformis and Bacillus subtilis were not inhibited by antiproteases from any of the clostridia in the present investigation. There seems to be a distinct serological difference between protease produced by the aerobic and anaerobic members of the family Bacillaceae.

Sandvik (1962) demonstrated that most proteases produced by aerobic and facultatively anaerobic bacteria were species-specific. However, within the genera Pseudomonas, Serratia, Proteus and Bacillus cross-reactions take place.

The present investigation gives substantial support to the views of Hausken, that cross-reactions between the different species of genus Clostridium occur to a large extent. While it is possible to use the electrophoretic CPI-test for taxonomic purposes for many aerobic and facultative anaerobic bacteria, the crossreactions within the genus Clostridium limit the possibilities of classifying different species within this genus by this method. This investigation indicates a serological relationship between proteases from the Clostridium species tested.

\section{REFERENCES}

Bulatova, T. I.\& Y. A. Kabanova: Identification of the botulism pathogen with luminescent sera. J. Microbiol. Epidem. Immunobiol. 1960, 31, 403-407.

Division of Microbiology, Bureau of Science, FDA: Serological studies of Clostridium botulinum. Report of the Spring 1969 Technical Meeting of the Interagency, Botulism Research Coordinating Committee (IBRCC) 1969. 
Fossum, $K$.: Proteolytic enzymes and biological inhibitors. II. Naturally occurring inhibitors in sera from different species and their effect upon proteolytic enzymes of various origin. Acta path. microbiol. scand. Section B. 1970, 78, 605-618.

Giménez, D. F. \& A. S. Ciccarelli: Another type of Clostridium botulinum. Zbl. Bakt. I. Abt. Orig. 1970a, 215, 221-224.

Giménez, D. F. \& A. S. Ciccarelli: Studies on strain 84 of Clostridium botulinum. Zbl. Bakt. I. Abt. Orig. 1970b, 215, 212-220.

Hausken, O. W.: Serological studies on proteolytic enzymes of genus Clostridium. Acta path. microbiol. scand. Section B 1967, 71, $387-392$.

Hobbs, G. \& A. W. Anderson: Protein differences in strains of Clostridium botulinum on separation by disc electrophoresis. In Ingram, M. \& T. A. Roberts, eds.: Botulism 1966. Chapman and Hall, London 1967, 417-421.

Lee, W. H. \& H. Riemann: Correlation of toxic and non-toxic strains of Clostridium botulinum by DNA-composition and homology. J. gen. Microbiol. 1970, 60, 117-123.

Mandia, J. W.: The position of Clostridium tetani within the serological scheme for the proteolytic Clostridia. J. infect. Dis. 1955, 97, 66-79.

Robertson, Muriel: Notes upon certain anaerobs isolated from wounds. J. Path. Bact. 1915-1916, 20, 327-349.

Sandvik, O.: Medier, reagenser og metoder i bakteriologisk laboratorieteknikk. (Media, reagents and methods in bacteriological laboratory technique). $72 \mathrm{pp}$. Veterinary College of Norway 1960, pp. 7 and 20.

Sandvik, O.: Studies on casein precipitating enzymes of aerobic and facultatively anaerobic bacteria. Thesis, $116 \mathrm{pp}$. Veterinary College of Norway 1962, pp. 13-41 and 73-86.

Smith, L. D. \& L. V. Holdeman: The pathogenic anaerobic bacteria. Charles C. Thomas, Springfield 1968, III, pp. 185-318.

Tjaberg, T. B.: Proteases of Clostridium botulinum. II. The relationship between growth medium and the production of proteases by Clostridium botulinum types A, B, C, D, E and F. Acta vet. scand. 1973a, 14, 193-200.

Tjaberg, T. B.: Proteases of Clostridium botulinum. III. Isolation and characterization of proteases from Clostridium botulinum types A, B, C, D and F. Acta vet. scand. 1973b, 14, 538-559.

Walker, P. D. \& Irene Batty: Fluorescent studies in the genus Clostridium. II. A rapid method for differentiating Clostridium botulinum types $A, B$ and $F$, types $C$ and $D$, and type E. J. appl. Bact. $1964,27,140-142$. 


\begin{abstract}
SAMMENDRAG
Clostridium botulinum proteaser. V. Sammenlignende serologiske undersøkelser mellom proteaser produsert av Clostridium botulinum og andre sporedannende bakterier.
\end{abstract}

En har unders $\varnothing k t$ det serologiske slektskap hos proteaser produsert av forskjellige stammer under genus Clostridium og genus Bacillus ved hjelp av antisera produsert på kanin. Ved hjelp av papirelektroforese skilte man de naturlige forekommende inhibitorer og antienzymene i serum og videre benyttet en kaseinpresipitasjon-hemmingsreaksjon (CPI-test). Proteaser produsert av Clostridium botulinum type A, B, C, D og F kryssreagerte med hverandre. Clostridium botulinum (stamme 84) ble hemmet av antiproteaser produsert mot Clostridium sporogenes og Clostridium botulinum type C og F (protease F I og F II), men ble ikke hemmet av antiproteaser mot Clostridium botulinum type B og F (protease F II), Clostridium bifermentans og Clostridium perfringens. Clostridium botulinum (stamme $89 \mathrm{G}$ ) ble hemmet av Clostridium sporogenes antiprotease, men ellers ikke. Ved hjelp av denne metoden er en ikke i stand til å skille serologisk mellom proteaser av Clostridium perfringens. Clostridium bifermentans protease ble hemmet bare av sitt homologe antiserum, mens Clostridium sporogenes protease kryssreagerte med Clostridium botulinum og Clostridium perfringens antiproteaser, men ikke med Clostridium bifermentans. Proteaser produsert av forskjellige Bacillus species ble ikke hemmet av antiproteaser mot Closiridium botulinum type $\mathrm{B}, \mathrm{C}$ og $\mathrm{F}$, Clostridium sporogenes, Clostridium bifermentans og Clostridium perfringens.

(Received August 21, 1973).

Reprints may be requested from: Tore Bjarne Tjaberg, the Norwegian Food Research Institute, Box 50, 1432 Ås-NLH, Norway. 